\begin{tabular}{|l|l|l|}
\hline \multicolumn{2}{|c|}{ PublisherInfo } \\
\hline \hline PublisherName & $:$ & BioMed Central \\
\hline \hline PublisherLocation & $:$ & London \\
\hline \hline PublisherImprintName & $:$ & BioMed Central \\
\hline \hline
\end{tabular}

\title{
ATM autophosphorylation
}

\begin{tabular}{|l|c|l||}
\hline \multicolumn{2}{|c|}{ ArticleInfo } \\
\hline \hline ArticleID & $:$ & 4692 \\
\hline \hline ArticleDOI & $:$ & $10.1186 /$ gb-spotlight-20030205-01 \\
\hline \hline ArticleCitationID & $:$ & spotlight-20030205-01 \\
\hline \hline ArticleSequenceNumber & $:$ & 44 \\
\hline \hline ArticleCategory & $:$ & Research news \\
\hline ArticleFirstPage & $:$ & 1 \\
\hline \hline ArticleLastPage & $:$ & 2 \\
\hline \hline & & RegistrationDate : 2003-2-5 \\
\hline ArticleHistory & $:$ & OnlineDate \\
\hline \hline ArticleCopyright & $:$ & BioMed Central Ltd2003-2-5 \\
\hline \hline ArticleGrants & $:$ & \\
\hline \hline ArticleContext & $:$ & 130594411 \\
\hline \hline
\end{tabular}




\section{Jonathan Weitzman}

Email: jonathanweitzman@hotmail.com

The ATM protein is a key signaling kinase that is activated by DNA damage and ionizing radiation. In the January 30 Nature, Christopher Bakkenist and Michael Kastan at St Jude Children's Research Hospital, Tennessee, USA, describe a novel mechanism by which ATM is maintained in the inactive state in normal cells and becomes activated in response to cellular radiation (Nature, 421:499-505, January 30, 2003). Bakkenist and Kastan observed that ATM becomes phosphorylated in response to ionizing radiation and identified serine 1981 as the phosphorylated residue. They generated polyclonal antibodies that recognized the phosphorylated serine to define the kinetics of ATM activation. ATM is phosphorylated as early as 5 minutes after irradiation and is sensitive to levels as low as 0.1 Gy which generates around 4 double-strand breaks in the genome. In normal cells ATM is held in an inactive dimer in which the ATM kinase domain is bound to the region around Ser1981. Bakkenist and Kastan propose a novel model for ATM regulation in which DNA breaks cause changes in chromatin structure that lead to inter-dimer autophosphorylation, dimer dissociation and activation of the DNA damage response pathway.

\section{References}

1. ATM: genome stability, neuronal development, and cancer cross paths.

2. Nature, [http://www.nature.com]

3. St Jude Children's Research Hospital, [http://www.stjude.org] 